\title{
IMPOSTO RESIDUAL SOBRE A PROPRIEDADE DE EMBARCAÇÕES E AERONAVES
}

\section{RESIDUAL TAX ON PROPERTY OF CRAFTS AND AIRCRAFTS}

Emanuele Longrova ${ }^{1}$

RESUMO: A constitucionalidade da desvinculação das receitas da União era questionada pela doutrina com fundamento, entre outros, no art. 154, I, da Constituição Federal. A Emenda Constitucional n. 93/2016 renova a importância desse dispositivo e nos impele a refletir sobre o exercício da competência tributária residual no tocante a imposto sobre a propriedade de embarcações e aeronaves.

Palavras-chave: Imposto. Propriedade. Embarcações. Aeronaves.

\begin{abstract}
The normative rule of unbinding of Federal Government's revenue was discussed by doctrine on the wording of the article 154, I of Federal Constitution, among others. In this way, the Constitutional Amendment n. 93/2016 brings new ideas on the application of such constitutional rule and stimulates new reflection on the Federal Government's competence to legislate on property tax over crafts and aircrafts.
\end{abstract}

http://revistasapereaude.org/index.php/edicoes/ano-5-volume-2-setembro-2016

D.O.I: $10.20523 /$ sapereaude-ano5-vol-2-pg-80-102 
Keywords: Tax. Property. Crafts. Aircrafts.

\section{INTRODUÇÃO}

$\mathrm{O}$ art. 76, do Ato das Disposições Constitucionais Transitórias (ADCT), que prescreve a desvinculação das receitas da União, era considerado inconstitucional pela doutrina, a qual apontava violação ao art. 154, I, da Constituição Federal, entre outros argumentos.

Recentemente, foi promulgada a Emenda Constitucional n. 93/2016, que prorrogou essas desvinculações e as estendeu às taxas; ainda, desvinculou receitas dos outros entes políticos ao incluir no ADCT os arts. 76-A e 76-B.

Em que pese com nova redação, as desvinculações continuam a existir para tributos por natureza destinados, o que permite manter aquela fundamentação para concluir pela inconstitucionalidade do mandamento.

Assim, mantém-se atual interpretar o art. 154, I, da Constituição. E, se esse é um dos dispositivos violados, podemos entender que sua aplicação em conformidade com o ordenamento se oferece como alternativa válida àquelas prescritas pela Emenda Constitucional n.93/2016.

Nesse contexto, pretendemos analisar se eventual imposto não cumulativo sobre a propriedade de embarcações e aeronaves pode ser instituído por lei complementar no exercício da competência tributária residual.

\section{COMPETENCIA TRIBUTÁRIA RESIDUAL}

http://revistasapereaude.org/index.php/edicoes/ano-5-volume-2-setembro-2016

D.O.I: 10.20523/sapereaude-ano5-vol-2-pg-80-102 
No contexto das desvinculações de receitas previstas no art. 76, do ADCT, Fabiana Del Padre Tomé (2013, p. 155-156) entende que parte da contribuição social se transforma em imposto, sem respaldo na norma de competência que prevê a destinação. Ademais, o art. 154, I, da CF, resta violado pela eventual exigência: a) de imposto com hipótese de incidência e base de cálculo próprias de imposto discriminado (no caso de contribuições "desvinculadas" com critério material semelhante ou idêntico ao de imposto); e b) de imposto não discriminado, baseado em critério material de contribuição "desvinculada".

Também Eduardo Marcial Ferreira Jardim (2015, p.120) se refere ao art.154, I, da CF, para se opor ao art. 76, do ADCT:

No tangente à questão pétrea, impende dizer que também se afigura procedente, porquanto o sistema tributário nacional constitucionalizado encontra-se pronto e acabado, não admitindo, sequer por hipótese, qualquer inovação além da instituição de impostos e contribuições de seguridade residuais, com fulcro no art. 154, inciso I, e impostos extraordinários de guerra, com supedâneo no inciso II do mesmo preceito normativo. Obviamente, por considerar que a Constituição abriu espaço apenas para duas hipóteses de modificação do sistema tributário, força é depreender que nenhuma outra figura poderia ser instituída que não aquelas enumeradas no art. 154, incisos I e II, tudo sob a égide da interpretação lógica do direito. Portanto, também sob a perspectiva do pleito, objeto do recurso sub examen, a indigitada DRU não resiste a um contraste de validade, ainda que oficialmente remanesça exigível por força do decisum da Corte Suprema.

A reiterada referência ao art. $154, \mathrm{I}$, da $\mathrm{CF}$, nos remete à competência tributária residual. Como observa Paulo de Barros Carvalho (2013, p. 244-245), a importância do estudo da competência residual pode ser justificada por uma perspectiva histórica: 
Ajeita-se aqui uma observação de cunho histórico, mas que nos parece procedente: há muito que a União dispõe de faixa residual de competência tributária. Em vez de movimentá-la, nas ocasiões em que necessitou, preferiu servir-se de expedientes desaconselháveis, como a singela mudança de nomes (chamando impostos pela designação de taxas, empréstimos compulsórios, contribuições e uma sorte de epítetos extravagantes). E a competência residual permaneceu inativa, decorando a tábua de possibilidades legiferantes do ente federal.

Sem negar a existência de outros sentidos atribuídos ao termo "tributo", nesse breve estudo ele será considerado norma jurídica tributária em sentido estrito, geral e abstrata, ou seja, regra-matriz de incidência tributária, oriunda do exercício da competência legislativa tributária.

O antecedente das normas jurídicas tributárias é tratado, pelo Código Tributário Nacional $^{2}$, como "fato gerador", expressão essa que sugere a hipótese de incidência de norma geral e abstrata, o fato jurídico tributário de norma individual e concreta e, até mesmo, o próprio evento fenomênico, revelando sua ambiguidade.

Na hipótese de incidência tributária, encontramos três critérios (CARVALHO, 2011, p. 323): o material, o espacial e o temporal. Núcleo da hipótese de incidência (CARVALHO, 2013, p. 468), o critério material indica o comportamento de pessoas, composto por um verbo e seu complemento, e a ele se volta o critério espacial, indicativo das notas de lugar ${ }^{3}$, e também o critério temporal, com as notas de tempo ${ }^{4}$.

O consequente da regra-matriz de incidência tributária alberga uma relação jurídica entre sujeitos (critério pessoal) em função de um objeto (no caso, o tributo na acepção de quantia em dinheiro), definido pela aplicação da alíquota à base de cálculo (critério quantitativo). 
Importa ressaltar, para os propósitos aqui perseguidos, que a base de cálculo é o desdobramento numérico do critério material da hipótese de incidência (SCHOUERI, 2013, p. 503504). Das funções que cumpre (CARVALHO, 2011, p. 400-405), destacamos a comparativa, segundo a qual a base de cálculo confirma, infirma ou afirma o critério material da hipótese (CARVALHO, 2010, p. 241) e, por fim, a própria espécie tributária, ou, ao menos, elimina algumas possibilidades.

Se a base de cálculo refletir conteúdo econômico diferente do que consta na hipótese de incidência, esta será repelida pela prevalência daquela (CARVALHO, 2010, p. 243). Em vista disso, ao tratarmos do binômio hipótese de incidência/base de cálculo, consideramos sobretudo o critério material da hipótese, a ser medido pela base de cálculo.

Advertidos com as considerações feitas sobre a locução "fato gerador", encontramos várias referências ao binômio hipótese de incidência/base de cálculo na Constituição Federal (art. 145, § 2; art. 146, III, “a”; art., 154, I). Mesmo na Constituição de 1967, com redação dada pela Emenda Constitucional n.1/1969, e especialmente no tema que nos interessa, havia essa referência nos arts. 18 e 21.

O binômio hipótese de incidência/base de cálculo se presta como critério para diferenciar as espécies tributárias no tocante à vinculação ou não do antecedente do tributo a uma atividade estatal, o que será capturado pela base de cálculo, como se infere do art. $145, \S 2^{\circ}$, ao afastar as taxas dos impostos. A classificação bipartida em tributos vinculados e não vinculados interessa-nos porque está no subsolo das discussões que levaram à aprovação da súmula vinculante n. 29, do Supremo Tribunal Federal.

http://revistasapereaude.org/index.php/edicoes/ano-5-volume-2-setembro-2016

D.O.I: $10.20523 /$ sapereaude-ano5-vol-2-pg-80-102 
Ademais, o binômio hipótese de incidência/base de cálculo também importa para exercício da competência residual da União ${ }^{5}$, tanto no caso dos impostos como das contribuições para custeio da seguridade social, em vista do art. 154, I, da CF, o que nos autoriza a aproximar alguns raciocínios utilizados na classificação das espécies tributárias em vinculadas e não vinculadas ao tema do exercício da competência tributária residual. Afastada a destinação dessas contribuições, elas podem se equipar a impostos no tocante ao "fato gerador" e base de cálculo.

A instituição de impostos ou contribuições diversos dos já discriminados na Constituição Federal exige um grande esforço para interpretação dos signos empregados pelo constituinte quando da rígida discriminação de competências, sob pena de ferir o limite representado pelo binômio hipótese de incidência/base de cálculo. Afinal, é preciso buscar o significado dos conceitos referidos quando da discriminação de competências tributárias entre os entes federativos para avaliar a originalidade de um novo binômio que embase o exercício da competência residual. É que a competência tributária residual não equivale, na rigidez característica do sistema tributário brasileiro, a um "cheque em branco"6.

\section{CARACTERÍSTICAS DO BINÔMIO HIPÓTESE DE INCIDÊNCIA/BASE DE CÁLCULO}

Nesse contexto, mister analisar o art. $145, \S 2^{\circ}$, da CF, segundo o qual as taxas não podem ter base de cálculo própria de impostos.

http://revistasapereaude.org/index.php/edicoes/ano-5-volume-2-setembro-2016

D.O.I: $10.20523 /$ sapereaude-ano5-vol-2-pg-80-102 
Interessante notar que o art. 77, parágrafo único, do CTN, determina que a taxa não pode ter base de cálculo ou "fato gerador" (binômio) idênticos aos que correspondam a imposto nem ser calculada em função do capital das empresas. Ainda o art. $18, \S 2^{\circ}$, da $\mathrm{CF}$ anterior, determinava que a taxa não poderia ter, como base de cálculo, a que tivesse servido para impostos, o que revela a opção do legislador constituinte pela relação de identidade.

Portanto, nesses diplomas normativos, temos como critério a relação de identidade; com a $\mathrm{CF} / 88$, o termo empregado passou a ser "próprio", mais abrangente do que o anterior, “idêntico”. Roque Antônio Carrazza ${ }^{7}$, ao comparar a redação do art. 145, §2º da CF de 1988, com o art. $18, \S 2^{\circ}$, da Constituição anterior, identifica um aperfeiçoamento do instituto. Luís Eduardo Schoueri ${ }^{8}$ também vê nisso um avanço.

Vejamos como a vedação do art. $145, \S 2^{\circ}$, da CF, foi sendo aplicada pelo Supremo Tribunal Federal, com destaque para a súmula n. $665^{9}$ e a súmula vinculante n. $19^{10}$.

Na súmula n. 665, a taxa de fiscalização dos mercados de títulos e valores mobiliários (Lei n. 7.940/1989) foi considerada constitucional. No caso, o valor da taxa varia conforme o patrimônio líquido da sociedade fiscalizada, o que sugere se tratar de um imposto, dada a capacidade contributiva inferida do patrimônio líquido ${ }^{11}$. Contudo, o Supremo Tribunal Federal entendeu que, apesar de referido, o patrimônio líquido não é a base de cálculo da taxa, operando de maneira complementar a ela, que deve espelhar invariavelmente o custo da fiscalização. Sendo exemplo de tributo fixo, a capacidade contributiva nessa taxa permite escalonar o custo da atividade estatal: quanto maior a empresa (conforme o patrimônio líquido), mais complexa e custosa será a fiscalização. Portanto, tem-se base de cálculo própria de taxa em torno da qual giram elementos típicos de impostos.

http://revistasapereaude.org/index.php/edicoes/ano-5-volume-2-setembro-2016

D.O.I: $10.20523 /$ sapereaude-ano5-vol-2-pg-80-102 
No julgamento do RE n. 576.321/QO-RG ${ }^{12}$, precedente para a edição da súmula vinculante n. 19, consignou-se o entendimento do Supremo Tribunal Federal de que o serviço público de coleta, remoção e tratamento ou destinação de lixo ou resíduos advindos de imóveis é específico e divisível, diferente do serviço público de conservação e limpeza de praças, ruas, calçadas, que é uti universi e insuscetível de remuneração via taxas. Essa taxa toma como referência de cálculo a área do imóvel, na suposição de que imóveis maiores produzem mais lixo. O ponto de desconcerto é que a área do imóvel é elemento próprio da base de cálculo (e, por conseguinte, da materialidade) de imposto predial e territorial urbano (IPTU), em aparente violação ao art. $145, \S 2^{\circ}$, da CF. Entretanto, aqui se fez o mesmo raciocínio da súmula n. 665 e se entendeu que a área do imóvel não compõe a base de cálculo em si da taxa, mas apenas aparece como expressão de capacidade contributiva de forma acessória ${ }^{13}$.

Há alguns anos, editou-se a súmula vinculante n. $2{ }^{14}$, que ora reproduzimos: "É constitucional a adoção, no cálculo do valor de taxa, de um ou mais elementos da base de cálculo própria de determinado imposto, desde que não haja integral identidade entre uma base e outra". Veja-se que nela há referência tanto à condição de "ser idêntico" como à de "ser próprio".

Nos debates sobre a proposta dessa súmula ${ }^{15}$, o Ministro Marco Aurélio consignou que a súmula poderia engessar a matéria com limitação do alcance do art. 145 , $2^{\circ}$, da $\mathrm{CF}$, beneficiando o credor do tributo e não o contribuinte, que se objetivou proteger. O Ministro Cezar Peluso, por sua vez, sugeriu que se alterasse a redação para: "é inconstitucional a taxa que tenha base de cálculo integralmente idêntica à de imposto", pois, com apenas um elemento diferente, não se teria nem a identidade integral, nem inconstitucionalidade. Ainda, a Ministra Cármen Lúcia ressaltou que o objetivo era que um tributo não fosse "decalque" outro, ou seja, que um não fosse 
uma imitação do outro, o que seria revelado pela base de cálculo (e aqui temos, mais uma vez, a função comparativa da base de cálculo).

Nesse contexto, é possível questionar se há uma identidade que não seja absoluta ou integral. Segundo a lógica alética, temos os princípios da identidade, da não contradição e do terceiro excluído. Com base neles, conclui-se que o objeto ou é "idêntico" ou é "não idêntico".

Em comentário ao julgamento do Recurso Extraordinário n. 232.393, Daniela Juliano Silva (2011,p. 15 - grifos originais ) explora a amplitude dos termos "idêntico" e "próprio":

Já naquela oportunidade, é possível concluir diante de citada decisão, que a Suprema Corte deu preferência, na análise do fato, pela redação mais elástica contida no parágrafo único do art. 77 do Código Tributário Nacional, que dispõe que a taxa não pode ter base de cálculo ou fato gerador idênticos aos que correspondem a imposto. Em uma interpretação gramatical de citada norma, podemos concluir que o Código Tributário Nacional foi menos, digamos, exigente, do que a norma Constitucional (parágrafo $2^{\circ}$ do artigo 145). O Código Tributário Nacional aos se utilizar do termo "idêntico", parece catalisar todos os interesses buscados, fornecendo o elemento necessário para abarcar as intenções acerca da real interpretação que se pretendia dar à matéria. Não há como negar que tal preferência se evidencia em total detrimento à vedação mais ampla contida no, já repetidamente citado, parágrafo $2^{\circ}$ do art. 145 da Constituição Federal de 1988. Seria desnecessário pontuar que tal opção se dá à mercê de norma tecnicamente superior (ofensa à supremacia formal da Constituição) à estatuída pelo Código Tributário Nacional, a evidenciar quebra de paradigmas elementares.

Pensamos que essa súmula, dependendo de como se interprete, pode representar um retrocesso àqueles dispositivos das décadas de 1960 e 1970 e trazer um mandamento contrário ao art. $145, \S 2^{\circ}$, da $\mathrm{CF}$, porque o critério volta a ser a ausência de identidade, quando, pela Constituição de 1988, ele é a ausência de peculiaridade (“ser próprio”). Bem explica Roque Antônio Carrazza (2013, p. 627): 
Em suma, é interdito às taxas terem a mesma base de cálculo dos impostos já existentes. Mas, mais do que isso, na fixação das bases de cálculo das taxas não poderão ser levados em conta índices de tributação típicos dos impostos, como, por exemplo, a renda, a despesa, o patrimônio etc.

Por isso, segundo Luís Eduardo Schoueri (2013, p. 513), essa súmula é criticável:

Está correta a afirmação da Súmula, se entendida em seu sentido estrito, i.e., que não há inconstitucionalidade na base de cálculo da taxa se um de seus elementos coincidir com o de imposto, já que é possível que haja alguma coincidência e ainda assim a base de cálculo reflita a atividade estatal; a redação adotada, entretanto, parece indicar que a inconstitucionalidade somente surgiria em caso de estrita identidade de bases de cálculo. Como visto acima, o mandamento constitucional é mais amplo, já que a base de cálculo própria (e não apenas idêntica) de impostos não serve para taxas.

Todos esses raciocínios podem ser aproveitados para se interpretar os demais dispositivos que nos remetem ao confronto entre "ser idêntico" e "ser próprio". Especialmente sobre a competência tributária residual, o art. 154, I, da CF, prescreve que os novos impostos não podem ter binômios próprios daqueles dos impostos discriminados, e não apenas idênticos, como se exigia na Constituição anterior (art. 18, $\S 5^{\circ}$ ).

Atento a que o art. $145, \S 2^{\circ}$, da $\mathrm{CF}$, também preserva o correto exercício da competência tributária residual, destaca Sacha Calmon Navarro Coelho (2005, p. 68):

[...] Não fosse essa regra, aparentemente miúda, dadas pessoas políticas poderiam criar fatos geradores e taxas com base de cálculo de imposto e, assim, burlar o sistema, provocando invasões de competências em áreas já reservadas às outras, com evidente sobrecarga tributária em desfavor dos contribuintes. A redação dada ao preceito pela Constituição de 1988 é melhor do que a dada pela de 1967 por mais uma razão. Agora, até mesmo as áreas tributáveis passíveis de ser exploradas 
por novos impostos (ainda não criados), com esforço na competência residual da União, restam preservadas. A redação da Constituição de 1967, com erronia, vedava base de cálculo idêntica à dos impostos existentes. Uma interpretação ao pé da letra levaria a limitar o alcance da vedação, sabendo que os exegetas oficiais são férteis em imaginação e despiste na miranda de aumentar as tributações ao arrepio das normas jurídicas".

Na premissa de que própria de taxa é a base de cálculo que reflete uma atuação estatal, e própria de imposto é aquela que reflete o signo de riqueza, qual seria, então, a hipótese de incidência e a base de cálculo, ou melhor, o binômio próprio de imposto? Simples: partindo-se do critério da vinculação, a hipótese de incidência de um imposto deve retratar uma conduta do particular não relacionada ao Estado, refletida na base de cálculo.

Na sequência, para aproveitar o raciocínio, é necessário refletir sobre a existência de um binômio próprio de cada imposto. Considerando, novamente, a função comparativa, obviamente a cada imposto corresponde uma grandeza medida pela base de cálculo, pois, medindo grandeza estranha ao fato, nega o tributo. No imposto sobre a renda, a base de cálculo é a dimensão da renda; no imposto sobre a propriedade, a base de cálculo é o valor dessa propriedade, e assim por diante. Trata-se da inerência a que se refere Luís Eduardo Schoueri (1998, p. 103 - grifos originais):

Chegamos, pois, à conclusão de que é o aspecto material do fato gerador o fator decisivo para a delimitação dos campos de competência de cada ente tributante, bem como para a definição da competência residual. Dada uma base de cálculo qualquer, ou bem será ela inerente ao elemento material do fato gerador que acompanha (e neste caso será despicienda a sua investigação, já que a ocorrência, ou não, de competência residual já se extrairá da comparação dos aspectos materiais dos fatos geradores), ou bem não servirá ela para medir o respectivo fato gerador (e neste caso será taxada de inconstitucional, por não atender à inerência que é pressuposta pela Constituição).

http://revistasapereaude.org/index.php/edicoes/ano-5-volume-2-setembro-2016

D.O.I: 10.20523/sapereaude-ano5-vol-2-pg-80-102 
Aplicando-se as conclusões sobre a súmula vinculante n. 29, podemos afirmar que cada imposto tem seu binômio próprio. Os impostos residuais, por sua vez, podem ter em seus binômios elementos dos binômios dos impostos discriminados, desde que se conservem binômios não próprios dos discriminados.

É preciso, inicialmente, avaliar se se está diante de um binômio idêntico ou não. Sendo idêntico, não há que se cogitar do exercício da competência residual. Mas, se for não idêntico, remanesce a possibilidade de ser próprio, porque essa é uma característica mais abrangente do que a de identidade e que também veda o exercício da competência tributária residual:

Tal situação será óbvia quando uma idêntica base de cálculo servir a dois impostos; havendo, entretanto, pequenas diferenças, caberá ao aplicador da lei dizer se, naquele caso, ambas as bases de cálculo seriam inerentes a um único aspecto material do fato gerador ou se cada base de cálculo é apta a medir apenas um aspecto material do fato gerador (SCHOUERI, 1998, p. 100).

Essas observações reforçam a necessidade de que o intérprete, empregando o percurso gerador de sentido (CARVALHO, 2011, p. 141), vença o plano da literalidade (S1) e, com norma construída (S3) e contextualizada (S4), esteja munido de ferramentas interpretativas que lhe permitam apurar, com rigor, um binômio próprio de imposto ou contribuição da seguridade social já existente, eventualmente camuflado numa "não identidade".

Adiante, veremos o caso da tributação sobre a propriedade de embarcações e aeronaves, não sujeitas a IPVA; a título residual, podemos imaginar um "imposto sobre a propriedade de embarcações e aeronaves".

http://revistasapereaude.org/index.php/edicoes/ano-5-volume-2-setembro-2016

D.O.I: $10.20523 /$ sapereaude-ano5-vol-2-pg-80-102 


\section{IMPOSTO RESIDUAL SOBRE A PROPRIEDADE DE EMBARCAÇÕES E}

AERONAVES

Considerando as manifestações do Supremo Tribunal Federal acerca da não incidência de imposto sobre a propriedade de veículos automotores (IPVA) sobre a propriedade de embarcações e aeronaves, identificamos campo para o exercício da competência tributária residual no tocante à propriedade de embarcações e aeronaves.

O constituinte outorgou aos Estados e ao Distrito Federal a competência para instituição do IPVA. Entretanto, não há norma geral em matéria tributária disciplinando o fato gerador e a base de cálculo desse imposto, conforme prescreve o art. 146, III, "a”, da CF. Em vista disso, entende-se que os Estados podem tributar a propriedade de veículos automotores até que seja editada a norma geral tributária via lei complementar ${ }^{16}$.

Segundo o anexo I, do Código de Trânsito Brasileiro (Lei n. 9.503/1997), veículo automotor é:

Todo veículo a motor de propulsão que circule por seus próprios meios, e que serve normalmente para o transporte viário de pessoas e coisas, ou para a tração viária de veículos utilizados para o transporte de pessoas e coisas. O termo compreende os veículos conectados a uma linha elétrica e que não circulam sobre trilhos (ônibus elétrico).

Rogério Lindenmeyer Vidal da Silva Martins (1997, p. 791-792), apoiado no art. $106^{17}$, do Código Brasileiro de Aeronáutica (Lei n. 7.565/1986), entende que veículo automotor tem

http://revistasapereaude.org/index.php/edicoes/ano-5-volume-2-setembro-2016

D.O.I: $10.20523 /$ sapereaude-ano5-vol-2-pg-80-102 
como requisito a propulsão por motor e que esse requisito é encontrado em algumas aeronaves, as quais poderiam ser englobadas pelo IPVA. Marcelo Knoepfelmacher entende que a expressão "veículo automotor" abrange o conceito de aeronaves, sendo constitucional a exigência de imposto sobre esses bens pelos Estados e Distrito Federal com base na competência atribuída pelo art. 155, III, da $\mathrm{CF}^{18}$. Luciano Garcia Miguel e Elaise Ellen Leopoldi também entendem que aeronaves e embarcações consistem em veículos automotores e podem ser tributados pelo imposto sobre a propriedade de veículos automotores ${ }^{19}$. Ricardo Alvarenga (1998, p. 65), ao contrário, sustenta que o conceito de aeronave é muito distante da definição de veículo automotor, sendo inexigível IPVA sobre sua propriedade.

Como se pode observar, mesmo chegando a conclusões diametralmente opostas, os autores consultados analisam o complemento do verbo do critério material da hipótese de incidência, um dos elementos do referido binômio, reforçando a imprescindibilidade do art.154, I, da CF, como critério interpretativo.

O IPVA surgiu com a Emenda Constitucional n. 27/1985, para substituir a antiga Taxa Rodoviária Única (TRU), que envolvia os veículos terrestres circulantes em rodovias. Em interpretação teleológica, Ricardo Alvarenga (1998, p. 65) indica esse fato como um dos fundamentos de sua conclusão acima indicada.

Tendo em vista essa circunstancia histórica, o Supremo Tribunal Federal afastou da abrangência do IPVA as aeronaves e embarcações, pois, caso contrário, estariam sujeitos a esse imposto quaisquer tipos de meio de transporte, inclusive animais. Como a TRU, que não abrangia as aeronaves e embarcações, foi substituída pelo IPVA, manteve-se a restrição:

http://revistasapereaude.org/index.php/edicoes/ano-5-volume-2-setembro-2016

D.O.I: $10.20523 /$ sapereaude-ano5-vol-2-pg-80-102 
EMENTA: Recurso Extraordinário. Tributário. 2. Não incide Imposto de Propriedade de Veículos Automotores (IPVA) sobre embarcações (Art. 155, III, CF/88 e Art. 23, III e $§ 13, \mathrm{CF} / 67$ conforme EC 01/69 e EC 27/85). Precedentes. 3. Recurso extraordinário conhecido e provido ${ }^{20}$.

EMENTA: IPVA - Imposto sobre Propriedade de Veículos Automotores (CF, art. 155, III; CF 69, art. 23, III e $\S 13$, cf. EC 27/85): campo de incidência que não inclui embarcações e aeronaves ${ }^{21}$.

Diante dessa posição do Supremo Tribunal Federal, o fato é que atualmente não incide IPVA sobre a propriedade de aeronaves e embarcações, a qual é, indubitavelmente, um signo de riqueza que pode cumprir os valores trazidos pelo princípio da capacidade contributiva. Segundo Luciano Garcia Miguel e Elaise Ellen Leopoldi (2003, p.27):

[...] A insistência de se afastar a incidência do IPVA da propriedade de aeronaves e embarcações acaba por tutelar interesses de contribuintes com maior capacidade contributiva do que a dos proprietários de veículos terrestres, prejudicando a orientações prevista no $\S 1^{\circ}$ do artigo 145 da nossa Lei Maior.

Assim, eventual imposto que abrigue em sua hipótese de incidência a propriedade de embarcações e aeronaves poderá ser instituído no exercício da competência tributária residual, através de lei complementar e observado o princípio da não cumulatividade, em atenção ao art. 154, I, da CF. Essa instituição será baseada no fato de que, apesar da identidade do verbo do critério material, seu complemento é, além de não idêntico, também não próprio, de acordo as decisões do Supremo Tribunal Federal acima citadas. Seguindo a mesma sorte, sua eventual base de cálculo poderá corresponder ao valor de mercado da embarcação ou aeronave usada, o valor constante no documento fiscal ou do documento de importação etc. 


\section{CONCLUSÃO}

Com a promulgação da EC n.93/2016, voltamos ao tema das desvinculações de receitas e, também, ao art. 154, I, da $\mathrm{CF}$, invocado pela doutrina como fundamento da inconstitucionalidade dessas medidas, entre outros argumentos.

Nesse contexto, a violação do art. 154, I, da CF, sugere que o exercício da competência tributária nele prevista possa se apresentar como alternativa às combatidas desvinculações.

Consoante posicionamento adotado pelo Supremo Tribunal Federal, podemos concluir que eventual imposto que abrigue em sua hipótese de incidência a propriedade de embarcações e aeronaves poderá ser instituído no exercício da competência tributária residual, pois, apesar da identidade do verbo do critério material, o complemento é, além de não idêntico, também não próprio.

\section{NOTAS}

${ }^{1}$ Mestra em Direito Tributário pela Pontifícia Universidade Católica de São Paulo - PUC/SP.

${ }^{2}$ Arts. 114 e seguintes.

http://revistasapereaude.org/index.php/edicoes/ano-5-volume-2-setembro-2016

D.O.I: $10.20523 /$ sapereaude-ano5-vol-2-pg-80-102 
${ }^{3}$ Paulo de Barros Carvalho (Direito tributário: linguagem e método. 5.ed. São Paulo: Noeses, 2013, p. 473) adverte que não é correto nos referirmos ao critério espacial como a própria condição de lugar, pois operamos no plano lógico das descrições hipotéticas: carregando critérios, não é o lugar em si, mas o instrumento para sua identificação.

4 “O marco de tempo deve assinalar o surgimento de um direito subjetivo para o Estado (no sentido amplo) e de um dever jurídico para o sujeito passivo". (CARVALHO, Paulo de Barros. Curso de direito tributário. 23.ed. São Paulo: Saraiva, 2011, p. 332).

5 "O legislador quando discerniu impostos e taxas escolheu como critério ter base de cálculo diferente. Em outro momento, quando quis criar a faixa de competência residual da União, que, por incrível que pareça, nunca foi utilizada, empregou o mesmo critério discriminador". (CARVALHO, Paulo de Barros. Direito tributário: linguagem e método. 5.ed., São Paulo: Noeses, 2013, p. 303).

6 “O sistema tributário nacional é, sem dúvida alguma, um sistema rígido, no sentido de que todas as competências tributárias, e todos os fatos tributáveis estão indicados na Constituição, admitindo esta a denominada competência residual, inclusive para as contribuições de seguridade, como visto, mas coloca limitações destinadas a evitar que o governo disponha de um verdadeiro 'cheque em branco"”. (MACHADO, Hugo de Brito. Competência residual e contribuições de seguridade social. In.: ROCHA, Valdir Oliveira (coord.). Contribuições previdenciárias: questões atuais. São Paulo: Dialética, 1996, p. 96).

7 'É interessante notar que a atual Constituição aperfeiçoou esta ideia ao estatuir, simplesmente, que ‘as taxas não poderão ter base de cálculo própria de impostos'”. (Curso de direito constitucional tributário. 29. ed. rev., ampl. e atual. São Paulo: Malheiros, 2013, p. 627).

http://revistasapereaude.org/index.php/edicoes/ano-5-volume-2-setembro-2016

D.O.I: $10.20523 /$ sapereaude-ano5-vol-2-pg-80-102 
8 “Ao adotar a expressão 'própria', o constituinte de 1988 agiu com rigor, exigindo que o jurista não apenas investigue se a base de cálculo de uma taxa foi utilizada por um imposto, mas também se ela seria própria de um imposto. Mais uma vez: própria de imposto é a base de cálculo que revela capacidade contributiva; própria de uma taxa é aquela que mede o serviço prestado ou a atividade estatal". (Direito tributário. 3. ed. São Paulo: Saraiva, 2013, p. 507).

9 “É constitucional a taxa de fiscalização dos mercados de títulos e valores mobiliários instituída pela lei 7940/1989”. (BRASIL. Supremo Tribunal Federal. Súmula n. 665. Aprovação: 24 set. 2003. Publicação: DJ 9 out. 2003, p. 4; DJ 10 out. 2003, p. 4; DJ 13 out. 2003, p. 4).

10 “A taxa cobrada exclusivamente em razão dos serviços públicos de coleta, remoção e tratamento ou destinação de lixo ou resíduos provenientes de imóveis, não viola o artigo 145, II, da Constituição Federal”. (BRASIL. Supremo Tribunal Federal. Súmula vinculante n. 19. Aprovação: 29 out. 2009. Publicação: DJe n. 210, 10 nov. 2009, p. 1; DOU 10 nov. 2009, p. 1).

11 Acerca disso, aduz Andrei Pitten Velloso (Constituição tributária interpretada. 2.ed. rev., atual. e ampl. Porto Alegre: Livraria do Advogado, 2012, p. 94 - grifos originais) que tal exação sequer poderia ser considerada uma taxa: “[...] Não é possível sequer qualifica-las como verdadeiras taxas; trata-se de exações heterogêneas, situadas numa zona gris entre os impostos e as taxas. São um engenhoso artifício para burlar a vedação do art. $145, \S 2^{\circ}$, da $C F$, que, lamentavelmente, foi bem sucedido, pois o STF chancelou a sub-reptícia violação da Lei Maior”.

12 BRASIL. Supremo Tribunal Federal. Recurso extraordinário n. 576.321/QO-RG. Relator: Ministro Ricardo Lewandowski. Julgamento: 4 dez. 2008. Publicação: DJe-030 13 fev. 2009.

http://revistasapereaude.org/index.php/edicoes/ano-5-volume-2-setembro-2016

D.O.I: $10.20523 /$ sapereaude-ano5-vol-2-pg-80-102 

CÁlCULO. IPTU. MUNICÍPIO DE SÃO CARLOS, S.P. I. - O fato de um dos elementos utilizados na fixação da base de cálculo do IPTU - a metragem da área construída do imóvel - que é o valor do imóvel (CTN, art. 33), ser tomado em linha de conta na determinação da alíquota da taxa de coleta de lixo, não quer dizer que teria essa taxa base de cálculo igual à do IPTU: o custo do serviço constitui a base imponível da taxa. Todavia, para o fim de aferir, em cada caso concreto, a alíquota, utiliza-se a metragem da área construída do imóvel, certo que a alíquota não se confunde com a base imponível do tributo. Tem-se, com isto, também, forma de realização da isonomia tributária e do princípio da capacidade contributiva: C.F., artigos 150, II, $145, \S 1^{\circ}$. II. - R.E. não conhecido".(BRASIL. Supremo Tribunal Federal. Recurso Extraordinário n. 232.393. Relator: Ministro Carlos Velloso. Julgamento: 12 ago. 1999. Órgão Julgador: Tribunal Pleno. Publicação: DJ 05 abr. 2002).

14 BRASIL. Supremo Tribunal Federal. Súmula vinculante n. 29. Aprovação: 3 fev. 2010. Publicação: DJe n. 28, 17 fev. 2010, p. 1; DOU 17 fev. 2010, p. 1.

${ }^{15}$ BRASIL. Supremo Tribunal Federal. Proposta de súmula vinculante n. 39 do Distrito Federal. Publicação: DJe n. 4512 mar. 2010.

16 “IMPOSTO SOBRE PROPRIEDADE DE VEÍCULOS AUTOMOTORES - DISCIPLINA. Mostra-se constitucional a disciplina do Imposto sobre Propriedade de Veículos Automotores mediante norma local. Deixando a União de editar normas gerais, exerce a unidade da federação a competência legislativa plena $-\S 3^{\circ}$ do artigo 24 , do corpo permanente da Carta de 1988 -, sendo que, com a entrada em vigor do sistema tributário nacional, abriu-se à União, aos Estados, ao Distrito Federal e aos Municípios, a via da edição de leis necessárias à respectiva aplicação - § $3^{\circ}$ 
do artigo 34 do Ato das Disposições Constitucionais Transitórias da Carta de 1988”. (BRASIL. Supremo Tribunal Federal. Agravo de Instrumento n. 500743 AgR. Relator: Ministro Marco Aurélio. Julgamento: 2 dez. 2010. Órgão Julgador: Primeira Turma. Publicação: DJe-042 03 mar. 2011).

17 Art. 106. Considera-se aeronave todo aparelho manobrável em vôo, que possa sustentar-se e circular no espaço aéreo, mediante reações aerodinâmicas, apto a transportar pessoas ou coisas.

18 “Por essas razões, entendemos que o conceito de 'veículos automotores' adotado pela Constituição, por ser mais amplo, abrange o conceito de 'aeronaves'(que é conceito mais restrito), sendo imperiosa a conclusão no sentido da constitucionalidade de instituição do IPVA pelos Estados sobre a propriedade de aeronaves, relativamente ao aspecto material da sua hipótese de incidência". (KNOEPFELMACHER, Marcelo. Aspectos da incidência do IPVA sobre a propriedade de aeronaves. Revista de Direito Tributário, n.79, 2000, p.222).

19 “Assim, os veículos automotores de qualquer espécie são indiscutivelmente máquinas, apesar da recíproca nem sempre ser verdadeira (nem toda máquina é veículo automotor). Entre os veículos autotomotres, sujeitos ao IPVA, incluem-se, portanto, as aeronaves e as embarcações automotoras". (MIGUEL, Luciano Garcia; LEOPOLDI, Elaise Ellen. Incidência do IPVA sobre aeronaves e embarcações. Revista Dialética de Direito Tributário, n.92, maio 2003, p.30).

${ }^{20}$ BRASIL. Supremo Tribunal Federal. Recurso Extraordinário n. 379572. Relator: Ministro Gilmar Mendes. Julgamento: 11 abr. 2007. Órgão Julgador: Tribunal Pleno. Publicação: DJe-018 01 fev.2008. 
${ }^{21}$ BRASIL. Supremo Tribunal Federal. Recurso Extraordinário n. 134509. Relator: Ministro Marco Aurélio. Relator para Acórdão: Ministro Sepúlveda Pertence. Julgamento: 29 maio. 2002. Órgão Julgador: Tribunal Pleno. Publicação: DJ 13 set. 2002.

\section{REFERÊNCIAS}

ALVARENGA, Ricardo. O IPVA na propriedade de aeronaves. Revista Dialética de Direito Tributário, n.29, p.65-70, fev. 1998.

CARRAZZA, Roque Antônio. Curso de direito constitucional tributário. 29. ed. rev., ampl. e atual. São Paulo: Malheiros, 2013.

CARVALHO, Paulo de Barros. Curso de direito tributário. 23.ed. São Paulo: Saraiva, 2011.

Direito tributário: fundamentos jurídicos da incidência tributária. 8.ed.rev., São Paulo: Saraiva, 2010.

. Direito tributário: linguagem e método. 5.ed. São Paulo: Noeses, 2013.

http://revistasapereaude.org/index.php/edicoes/ano-5-volume-2-setembro-2016

D.O.I: $10.20523 /$ sapereaude-ano5-vol-2-pg-80-102 
COELHO, Sacha Calmon Navarro. Comentários à Constituição de 1988: sistema tributário. Rio de Janeiro: Forense, 2005.

JARDIM, Eduardo Marcial Ferreira. Finanças públicas e tributação: ao lume dos direitos e garantias. São Paulo: Noeses, 2015.

KNOEPFELMACHER, Marcelo. Aspectos da incidência do IPVA sobre a propriedade de aeronaves. Revista de Direito Tributário, n.79, p.215-230, 2000.

MACHADO, Hugo de Brito. Competência residual e contribuições de seguridade social. In.: ROCHA, Valdir Oliveira (coord.). Contribuições previdenciárias : questões atuais. São Paulo: Dialética, 1996.

MARTINS, Rogério Lindenmeyer Vidal da Silva. O perfil constitucional do imposto sobre a propriedade de veículos automotores - IPVA. In.: MARTINS, Ives Gandra (coord.). Curso de direito tributário. 5.ed. Belém: CEJUP, 1997, p. 785-800.

http://revistasapereaude.org/index.php/edicoes/ano-5-volume-2-setembro-2016

D.O.I: $10.20523 /$ sapereaude-ano5-vol-2-pg-80-102 
MIGUEL, Luciano Garcia; LEOPOLDI, Elaise Ellen. Incidência do IPVA sobre aeronaves e embarcações. Revista Dialética de Direito Tributário, n.92, p.26-32, maio 2003.

SCHOUERI, Luís Eduardo. Direito tributário. 3. ed. São Paulo: Saraiva, 2013.

Discriminação de competências e competência residual. In: Direito tributário: estudos em homenagem a Brandão Machado. São Paulo: Dialética, 1998.

SILVA, Daniela Juliano. Súmula vinculante n. 29 - uma nova dogmática tributária?. Revista Dialética de Direito Tributário. São Paulo, n. 190, p. 9-18, jul. 2011.

TOMÉ, Fabiana Del Padre. Contribuições para a Seguridade Social: à luz da Constituição Federal. 2.ed. Curitiba: Juruá, 2013.

VELLOSO, Andrei Pitten. Constituição tributária interpretada. 2.ed. rev., atual. e ampl. Porto Alegre: Livraria do Advogado, 2012.

http://revistasapereaude.org/index.php/edicoes/ano-5-volume-2-setembro-2016

D.O.I: $10.20523 /$ sapereaude-ano5-vol-2-pg-80-102 